\title{
SOME ISSUES AND PROSPECTS \\ OF DEVELOPING ENTREPRENEURIAL COMPETENCY IN FUTURE BACHELORS IN BUSINESS ECONOMICS DURING PROFESSIONAL TRAINING
}

\author{
Inna Seredina, \\ Postgraduate Student of the Institute of Vocational Education and Training of NAES of Ukraine Head of University Laboratory of \\ The Philosophy and Pedagogy Department at National Transport University, Kyiv \\ https://orcid.org/0000-0002-4220-0006, e-mail: innaseredina@ukr.net
}

\begin{abstract}
.
The relevance of this research lies in the intensive development of higher economic education in Ukraine and the strong demand of society and Ukraine's economics for the specialists ready to pursue a professional career under the conditions of small business development.

Aim: the paper aims to identify and describe the current issues and prospects of developing entrepreneurial competency in future bachelors in business economics during professional training.

Methods: a classic analysis of official documents and scientific works on the issue of developing entrepreneurial competency: external analysis (taking into account the historical circumstances of the creation of selected documents as elements of a particular system of socio-economic relations; determining its importance and effectiveness given specific research issues); internal analysis (focusing on the content of the source; identifying some issues and prospects of developing entrepreneurial competency in future specialists during professional training in HEIs):

Results. The paper shows that modern scholars have different views on the concept of entrepreneurship. However, they agree that the success of entrepreneurial activity depends on graduates' entrepreneurial competency. The paper indicates that modern bachelors in economics must be well-rounded, intelligent, highly-cultured and well-mannered, competent in commercial matters and continuously enhance their professionalism, given the needs of Ukraine's economic development. Besides, it proves that entrepreneurial competency is mostly understood as a set of personal and business qualities, skills, knowledge, behaviour models, which help to solve specific economic issues and achieve high results.

Conclusions. The paper identifies the primary issues of developing entrepreneurial competency in future bachelors in business economics. They are as follows: students' lack of motivation to show entrepreneurial initiative; unreadiness for entrepreneurial activity; unacceptable levels of entrepreneurial competency; inefficient degree programmes; a particular imbalance between professional and core competencies. Also, the paper outlines the prospects of developing entrepreneurial competency in future bachelors in business economics. They involve reforms in the system of national education; the development and implementation of the author's programmes in economic courses; the introduction of specialized courses for developing entrepreneurial competency; the digitalization of higher education; the implementation of innovative international experience in training for entrepreneurial activity into the practice of Ukrainian HEIs.
\end{abstract}

Keywords: entrepreneurship, business economics, competency, entrepreneurial competency, bachelor's degree. 
Introduction. Recent changes in society, economics, higher education and the state system propose a new paradigm of human capital development in Ukraine. The development of higher economic education in Ukraine requires the use of new educational technologies, which can help to train graduates ready for professional activities and with a high level of professional and economic culture, as well as entrepreneurial competency. Under the conditions of a market economic system, it is essential to prepare young people for changes and help them to adapt to radical transformations in the social and economic life of society. It is possible only if they have a sufficient level of entrepreneurial competency, which will assist them in achieving real success in any field of professional activities. In this regard, HEIs must provide relevant conditions for training not only specialists with relevant knowledge but also competitive and creative employees. Therefore, the development of entrepreneurial competency in young people should aim to develop an entrepreneurial culture in society since it is essential for the country's economic growth.

Sources. Many sources indicate that entrepreneurial competency is developed based on specific innate abilities, some of which can be developed and acquired with experience. Scientific literature shows that only $11 \%$ of the population have entrepreneurial skills (Vasyltsiv, 2009). Such opinions are quite controversial, even though having long-standing historical roots. Using scientific tools of geocultural, ethnocultural, socio-cultural, biographical, typological and other approaches, L. Yershova (2018a) conducts a historical analysis of the causes and effects of changes in the image of Ukrainian multinational economic elite during the 19th century - the early 20th century, especially their relation to entrepreneurship and economic education.

R. Hizrich \& M. Piters (1992) believe that one can easily teach business to those people who have a natural ability for it. Thus, they identify 14 competencies necessary for entrepreneurship. They are critical thinking, abilities to make non-standard decisions, initiate new ideas, evaluate prospects, readiness to open a new business, creative and critical evaluation of work situations, the conclusion of agreements, stress resistance, moral and ethical culture, communication skills to establish contacts and conduct negotiations.

According to V. Maikovska (2017), entrepreneurial competency is developed based on professional economic training (education). It includes a well-developed motivation to show entrepreneurial initiative, skills of successful business activity, knowledge about current business legislation, readiness for self-development and self-realization, ability to navigate in economic and financial categories.

Despite many studies on entrepreneurial compe- tency, Ukrainian scholars interpret entrepreneurship in different contexts. Justifying the goals of developing entrepreneurial competency, some scholars prioritize profit-making, whereas others focus on innovative and non-standard approaches to solving matters or the risky nature of commercial and economic activities. However, they agree on the fact that the success of business depends on the level of core competencies (Zakatnov, 2007; 2009; 2015; Lemeshko, 2018; Odnoroh, 2018; Radkevych, 2016; Yablunovska, 2018).

The paper analyzes the Concept of Development of Economic Education, decrees of the Cabinet of Ministers of Ukraine, the State Standard of Higher Professional Education Regarding a Bachelor's Degree in Economics (Specialty 051) and the National Framework of Qualifications. Summarizing these legal documents and recent research, the author of the paper concludes that entrepreneurial competency is viewed as a set of personal and business qualities, skills, knowledge, behaviour models, which help to solve specific economic issues, engage in self-management, show initiative, take appropriate risks.

The paper aims to identify and describe the current issues and prospects of developing entrepreneurial competency in future bachelors in business economics during professional training.

Methods: a classic analysis of official documents and scientific works on the issue of developing entrepreneurial competency: external analysis (taking into account the historical circumstances of the creation of selected documents as elements of a particular system of socio-economic relations; determining its importance and effectiveness given specific research issues); internal analysis (focusing on the content of the source; identifying some issues and prospects of developing entrepreneurial competency in future specialists during professional training in HEIs), as well content analysis of certain legal documents.

Results and discussion. Modern Ukrainian scholars regard bachelors in economics as intellectuals with a broad scientific outlook, a stable civic culture and well-developed entrepreneurial competency, who are ready for personal and professional development. The Concept of Development of Economic Education in Ukraine also focuses on the training of well-rounded professionals, active members of society with a broad scientific outlook and a talent for self-realization. However, the development of economic education should be accessible, open, systematic and continuous, combining the professionalism of degree programmes and innovative content (Verkhovna Rada of Ukraine. Legislation of Ukraine, 2003).

The modern labour market needs competent specialists. The concept of competency is comprehensive and includes not only knowledge but also specific competencies implying abilities, skills and moral 
values. Still, graduates need to be able to act effectively not only in educational but also in other fields. It refers to the situations when it is necessary to solve some issues, clarify their conditions and evaluate the obtained results independently. Education should aim to train specialists with a high level of knowledge who can think, acquire and apply knowledge in practice. Therefore, it is crucial to choose the appropriate educational content, means, forms and methods that provide more significant opportunities for both development and self-realization of the individual.

Higher education training lay the foundations of professionalism and develop the skills of independent professional activity. Therefore, students should realize that independent work completes all other types of educational work since knowledge not required for professional activities is not a real property of the specialist. Today, lecturers use a wide range of different types of activities to teach students to work independently: exercises, tasks, study of educational literature, reviewing and annotating, various types of note-taking (extracts, abstracts), preparation of written reports (abstracts, articles), structural and logical schemes of lectures, various projects.

In the system of modern higher education, there are also some issues decreasing students' motivation towards educational and cognitive activities, self-development and self-study. They are the results of students' difficult adaptation to real working conditions, inability to apply the obtained theoretical knowledge and economic tools. Some graduates do not have the necessary knowledge about starting their business, the principles of the tax system and the mechanisms of economic analysis. They cannot summarize the acquired knowledge and apply it in practice. Bachelor programmes in business economics do not balance general scientific, professional and specialized courses, which negatively affects the educational process (Yevtushevskyi, 2002; Poiasok, 2003; Tkalenko, 2011). Thus, it is essential to improve the educational process in HEIs which provide degree programmes in economics.

Some scholars suggest that reforms in higher economic education should focus on the use of innovative educational technologies, multifunctional interdisciplinary links, independent work in the educational process, a collaboration between educators and stakeholders. It is also vital to implement scientific results of students and lecturers into practice (Kovalchuk, 1999). Thus, professional training of future bachelors in business economics should be considered as a process of developing students' competencies, motivating them towards self-study and self-development, as well the ability to organize the educational process independently.

Research activities are also beneficial for future specialists in business economics since such activities can help to develop their professional competency rather effectively and reveal the potential of every student (Haiduchenko, 2015). Doing some research, students learn to see and analyze problem situations. Cognition occurs through the implementation of three main activities. They involve creating a personal, educational product; comprehending the profession and the self in it; organizing cognition and creation. It will allow future bachelors in business economics to use the basic types of professional activities and diversify professional results.

Entrepreneurial competencies are prognostic, methodological, communicative and in demand in the modern world. In other words, every graduate must be an entrepreneur in one way or another. In the context of education, entrepreneurship aims to unlock a personal potential of individuals so that the student is seen as unique integrity in the ability to achieve specific goals. Entrepreneurs do not just perform some functions. First of all, they implement their ideas. They need to be aware of and identify their capabilities, as well as to take responsibility for the risks of exceeding them. They should be able to evaluate the future effects of their actions and defend their entrepreneurial strategies reasonably. Therefore, entrepreneurs need to be able to act individually (self-confidence; abilities to engage in dialogue, defend their viewpoints, understand alternative viewpoints, reach a compromise, evaluate economic situations adequately, find optimal business decisions).

A well-developed entrepreneurial competency of future economists is one of the requirements of the State Standard of Higher Professional Education Regarding a Bachelor's Degree in Economics (Specialty 051). The idea of complex and systematic training of students for entrepreneurship is becoming more and more critical regarding the organization of the educational process in HEIs. Although Ukrainian HEIs have gained considerable experience in training future bachelors in business economics, they do not meet the needs of the modern labour market caused by the digital revolution and the following socio-economic processes (Bazeliuk, 2018; Yershov, 2019).

Besides, one should pay much attention to understanding competency as a set of knowledge, skills and personal qualities needed to perform different entrepreneurial tasks. Therefore, it is essential to balance the professional and core competencies necessary for developing entrepreneurial competency (Zakatnov, 2007; Yershova, 2018b). The following components of economic training should be viewed as psycho-pedagogical conditions for developing entrepreneurial competency: clarifying educational goals and objectives; providing educational guidance; boosting students' motivation towards self-study; 
allocating more hours to independent work; making students more aware of possible mechanisms, methods, forms and results of economic training; improving the educational process; using new information technologies and the Internet; preparing teaching staff for developing students' economic culture; specifying psychological characteristics of individuals and their focus on economic activities.

Practical training of future bachelors in business economics takes place throughout the whole period of study. It includes industrial, economic and pre-diploma types of practice, which focus on different tasks but pursue a single purpose, namely, to provide students with practical experience. As a result, students establish strong links with production. New specialists do not feel themselves as "newcomers" in the labour market since they are more competitive and have practical experience in addition to theoretical knowledge. After graduating, most specialists in business economics work in the companies where they did their practice. Besides, students need to prepare course papers and practically all qualifying bachelor theses based on the experience gained from working in real companies.

Conclusions. The studies on entrepreneurship as a pedagogical phenomenon and the results from the analysis of a current legal framework for professional training of future economics specialists for entrepreneurship show that there are specific issues in the context of the research issue. They are the following:

- although the system of higher education in Ukraine has gained some positive experience in training future bachelors in business economics, the socio-economic processes and the development of production and companies necessitate constant adjustments to its content in both theoretical and applied aspects, which HEIs are unable to ensure on time;

- traditional professional training of bachelors in business economics cannot fully ensure the quality training of future economists who should able to solve complex problems of the country's economic development;

- HEIs lack robust mechanisms of employers and students' influence on building the content of degree programmes, which results in low levels of entrepreneurial competency in future specialists in business economics;

- HEIs formally acknowledge the importance of soft and digital skills in training specialists ready for professional success; yet, they cannot achieve a precise balance in developing professional and core competencies necessary for developing entrepreneurial competency;

- little importance given to social and humanities courses in HEIs not specializing in humanities results in the low motivation of graduates to show entrepreneurial initiative and readiness for entrepreneurial activity.

The steps necessary for improving mechanisms of developing entrepreneurial competency in HEIs are as follows:

- approving standards of higher education;

- updating the system of national education taking into account a competency-based approach;

- improving mechanisms of developing entrepreneurial competency by developing and implementing the author's programmes of economic courses;

- introducing specialized courses aimed at developing entrepreneurial competency;

- studying the experience of teaching economics in HEIs in developed countries;

- introducing innovative international experience into Ukrainian HEIs, taking into account the peculiarities of Ukraine's economic development and mentality;

- creating relevant conditions in HEIs for improving a digital culture of graduates.

Further research should aim to define criteria, indicators and levels of development of entrepreneurial competency in future bachelors in economics during professional training.

\section{List of references}

Базелюк, О., 2018. Зміст і структура цифрової культури педагогічних працівників закладів професійної освіти. Науковий вісник Інституту професійно-технічної освіти НАПН Украӥни. Професійна педагогіка, 16, с. 81-87. DOI: http://doi.org/10.32835/2223-5752.2018.16.81-87.

Васильців, Т.Г., 2009. Удосконалення державного регулювання підприємницької діяльності в Україні. Стратегічні пріоритети, 1(10), с. 145-149

Верховна Рада України. Законодавство України, 2003. Концепція розвитку економічної освіти в Україні. [online] Доступно: https://zakon.rada.gov.ua/rada/show/v12_7290-03/sp:max25 [Дата звернення 09 грудня 2019]

Верховна Рада України. Законодавство України, 2014. Закон України «Про вищу освіту». [online] (Останнє оновлення 06 Червень 2019) Доступно: <http://zakon5.rada.gov.ua/laws/show/1556-18>. [Дата звернення 10 Травня 2019].

Гайдученко, Ю.О., 2015. Реалізація індивідуального підходу до навчання та самореалізація студентів економічних спеціальностей. Педагогіка та психологія, 51, с. 22-28.

Свтушевський, В.А., 2002. Економічна освіта у вищій школі: здобутки та перспективи формування. Вищза освіта Украӥни, 2, с. 86-91.

Єршов, М.-О., 2018. Роль української ІТ-освіти на світовому ринку інформаційних товарів і послуг. Науковий вісник Інституту професійно-технічної освіти НАПН Украӥни. Професійна педагогіка, 16, c. 74-81. DOI: http:// doi.org/10.32835/2223-5752.2018.16.74-81. 
Єршова, Л., 2015. Формування референтної особистості як проблема освітньої практики сучасної України. Вісник Черкаського університету. Серія: Педагогічні науки, 6, с. 119-124.

Єршова, Л., 2018а. Від купця - до підприємця: трансформація цінностей української економічної еліти у ХІХ - на початку XX століття. Науковий вісник Інституту професійно-технічної освіти НАПН Украӥни. Професійна педагогіка, 15, с. 154-161. https://doi.org/10.32835/2223-5752.2018.15.

Єршова, Л., 2018b. Трансформація системи цінностей учнівської і студентської молоді в контексті реформування вітчизняної професійної освіти. Науковий вісник Інституту професійно-технічної освіти НАПН України. Професійна педагогіка, 16, с. 162-168. DOI: http://doi.org/10.32835/2223-5752.2018.16.162-168.

Закатнов Д., 2007. Організаційно-педагогічне забезпечення підготовки учнівської молоді до планування кар'єри. Теоретико-методичні проблеми виховання дітей та учнівської молоді, 10 (II), с. 373-380.

Закатнов, Д.О., 2009. Стан і проблеми професійної орієнтації. Професійно-технічна освіта: інноваційний досвід, перспективи, 1(6), с. 173-179.

Закатнов, Д., 2015. Профорієнтаційні засади кар'єрного розвитку учнівської молоді. Науковий вісник Інституту професійно-технічної освіти НАПН України. Професійна педагогіка, 9, с. 86-94.

Кабінет Міністрів України, 2019. Постанова Кабінету Міністрів України «Про затвердження переліку галузей знань та спеціальностей, за якими здійснюеться підготовка здобувачів вищої освіти». [online] (Останне оновлення 06 Червень 2019) Доступно: <http://www.kmu.gov.ua/control/ru/cardnpd?docid=248149695> [Дата звернення 11 Травень 2019].

Ковальчук, Г.О., 1999. Активізація навчання в економічній освіті. Навчальний посібник. Київський національний економічний університет. К.: КНЕУ.

Лемешко Л., Формування художньо-творчої компетентності техніків-конструкторів одягу як проблема професійної педагогіки. Науковий вісник Інституту професійно-технічної освіти НАПН Украӥни. Професійна педагогіка, 16, с. 100-104. https://doi.org/10.32835/2223-5752.2018.16.100-104.

Майковська, B.I., 2017. Сутність і структура підприємницької компетентності майбутніх фахівців в Україні. Вісник Житомирського державного університету імені Івана Франка. 1, с. 112-117.

Однорог, Г., 2018. Теоретичні засади формування ключових компетентностей учнів у закладах професійної освіти засобами інтерактивних технологій. Науковий вісник Інституту професійно-технічної освіти НАПН Украӥни. Професійна педагогіка, 16, с. 104-108. https://doi.org/10.32835/2223-5752.2018.16.104-108.

Поясок, Т.Б, 2003. Принципи відбору змісту психолого-педагогічної підготовки майбутніх економістів. Неперервна професійна освіта: Теорія і практика, 1, с. 200-204.

Радкевич, В., 2016. Теоретичні та методичні засади розвитку професійної освіти і навчання: результати, проблеми, перспективи. Науковий вісник Інституту професійно-технічної освіти НАПН України. Професійна педагогіка, 11, с. 5-22.

Радкевич, О.П., 2012. Особливості правового регулювання мережі Інтернет. Право та управління, 1, с. $436-443$.

Ткаленко, Н.В., 2011. Проблеми підготовки сучасних економістів у системі вищої освіти. Науковий вісник ЧДІЕУ, 3 (11), с. 31-35

Хизрич, Р. и Питерс, М., 1992. Предпринимательство, или как завести собственное дело и добиться успеха. Bыл. 1. Предприниматель и предпринимательство. Перевод с английского И. И. Андреева, Е. Н. Николаенко. М.: Прогресс-Универс.

Яблуновська, К., 2018. Теоретичні основи формування екологічної компетентності майбутніх викладачів аграрних закладів вищої освіти. Науковий вісник Інституту професійно-технічної освіти НАПН Украӥни. Професійна педагогіка, 15, с. 47-53. https://doi.org/10.32835/2223-5752.2018.15.47-53.

Yershov, M.-O., 2019. Digitalisation of professional (vocational) and pre-high tertiary education of Ukraine: problems and prospects. Scientific herald of the Institute of vocational education and training of NAES of Ukraine. Professional Pedagogy, 1(18), pp. 67-74. https://doi.org/10.32835/2223-5752.2019.18.67-74.

\section{Translated \& Transliterated}

Bazeliuk, O., 2018. Zmist i struktura tsyfrovoi kultury pedahohichnykh pratsivnykiv zakladiv profesiinoi osvity [Content and structure of digital culture of VET institutions' teachers]. Naukovyi visnyk Instytutu profesiino-tekhnichnoi osvity NAPS Ukrainy. Profesiina pedahohika [Scientific herald of the Institute of vocational education and training of NAES of Ukraine. Professional Pedagogy], 16, s. 81-87. DOI: http://doi.org/10.32835/2223-5752.2018.16.81-87, [in Ukrainian].

Vasyltsiv, T.H., 2009. Udoskonalennia derzhavnoho rehuliuvannia pidpryiemnytskoi diialnosti v Ukraini [Improvement of state regulation of business activity in Ukraine]. Stratehichni priorytety [Strategic priorities]. 1(10), s.145-149, [in Ukrainian].

Verkhovna Rada Ukrainy. Zakonodavstvo Ukrainy [Verkhovna Rada of Ukraine. Legislation of Ukraine], 2003. Kontseptsiia rozvytku ekonomichnoi osvity v Ukraini [The concept of economic education development in Ukraine]. [online] Dostupno: <https://zakon.rada.gov.ua/rada/show/v12_7290-03/sp:max25> [Data zvernennia 09 hrudnia 2019], [in Ukrainian].

Verkhovna Rada Ukrainy. Zakonodavstvo Ukrainy [Verkhovna Rada of Ukraine. Legislation of Ukraine], 2014. Zakon Ukrainy «Pro vyshchu osvitu» [The Law of Ukraine about «High Education»]. [online] (Ostannie onovlennia 06 Cherven 2019) Dostupno: <http://zakon5.rada.gov.ua/laws/show/1556-18>. [Data zvernennia 10 Travnia 2019], [in Ukrainian].

Haiduchenko, Yu.O., 2015. Realizatsiia indyvidualnoho pidkhodu do navchannia ta samorealizatsiia studentiv ekonomichnykh spetsialnostei [Implementing an individual approach to training and self-realization of economics students]. Pedahohika ta psykholohiia [Pedagogics and Psychology], 51, s. 22-28, [in Ukrainian]. 
Yevtushevskyi, V.A., 2002. Ekonomichna osvita u vyshchii shkoli: zdobutky ta perspektyvy formuvannia [Economic education in higher education: achievements and prospects of formation]. Vyshcha osvita Ukrainy [High education in Ukraine], 2, s. 86-91, [in Ukrainian].

Yershov, M.-O., 2018. Rol ukrainskoi IT-osvity na svitovomu rynku informatsiinykh tovariv i posluh [The role of Ukrainian IT education in the world market of information products and services]. Naukovyi visnyk Instytutu profesiinotekhnichnoi osvity NAPS Ukrainy. Profesiina pedahohika [Scientific herald of the Institute of vocational education and training of NAES of Ukraine. Professional Pedagogy], 16, s. 74-81. DOI: http://doi.org/10.32835/2223-5752.2018.16.7481, [in Ukrainian].

Yershova, L., 2015. Formuvannia referentnoi osobystosti yak problema osvitnoi praktyky suchasnoi Ukrainy [The reference individual formation as a problem of the educational practices in modern Ukraine]. Visnyk Cherkaskoho universytetu. Seriia: Pedahohichni nauky [Cherkasy university bulletin: Pedagogical sciences], 6, s. 119-124, [in Ukrainian].

Yershova, L., 2018. Vid kuptsia - do pidpryiemtsia: transformatsiia tsinnostei ukrainskoi ekonomichnoi elity u XIX - na pochatku XX stolittia [From a tradesman to an entrepreneur: the Ukrainian business leaders' values transformation in XIX and early XX centuries]. Naukovyi visnyk Instytutu profesiino-tekhnichnoi osvity NAPS Ukrainy. Profesiina pedahohika [Scientific herald of the Institute of vocational education and training of NAES of Ukraine. Professional Pedagogy], 15, s. 154-161, [in Ukrainian].

Yershova, L., 2018. Transformatsiia systemy tsinnostei uchnivskoi i studentskoi molodi v konteksti reformuvannia vitchyznianoi profesiinoi osvity [Transformation of the students' values system in the context of domestic vocational education and training reforming]. Naukovyi visnyk Instytutu profesiino-tekhnichnoi osvity NAPS Ukrainy. Profesiina pedahohika [Scientific herald of the Institute of vocational education and training of NAES of Ukraine. Professional Pedagogy], 16, s. 162-168. DOI: http://doi.org/10.32835/2223-5752.2018.16.162-168, [in Ukrainian].

Zakatnov, D.O., 2007. Orhanizatsiino-pedahohichne zabezpechennia pidhotovky uchnivskoi molodi do planuvannia kariery [Organizational and pedagogical support of training pupils to build a career]. V: Teoretyko-metodychni problemy vykhovannia ditei ta uchnivskoi molodi: zb. nauk. pr. [Theoretical and methodical problems in character building of children and pupils]. K.: In-t problem vykhovannia APN Ukrainy, s. 373-380, [in Ukrainian].

Zakatnov, D.O., 2009. Stan i problemy profesiinoi oriientatsii [The conditions and problems of professional orientation]. Profesiino-tekhnichna osvita: innovatsiinyi dosvid, perspektyvy [Professional (vocational) education: an innovative experience and prospects], 1(6), s. 173-179, [in Ukrainian].

Zakatnov, D., 2015. Proforiientatsiini zasady kariernoho rozvytku uchnivskoi molodi [Professional orientation and proforientologic competences concerning vocational self-determination and career development of young students]. Naukovyi visnyk Instytutu profesiino-tekhnichnoi osvity NAPS Ukrainy. Profesiina pedahohika [Scientific herald of the Institute of vocational education and training of NAES of Ukraine. Professional Pedagogy], 9, s. 86-94, [in Ukrainian].

Kabinet Ministriv Ukrainy [Cabinet of Ministers of Ukraine], 2019. Postanova Kabinetu Ministriv Ukrainy «Pro zatverdzhennia pereliku haluzei znan ta spetsialnostei, za yakymy zdiisniuietsia pidhotovka zdobuvachiv vyshchoi osvity» [Decree the cabinet of Ministers of Ukraine about «Approval of the list of disciplines and specialties, which are trained candidates of High Education»]. [online] (Ostannie onovlennia 06 Cherven 2019) Dostupno: <http://www.kmu.gov.ua/ control/ru/cardnpd?docid=248149695> [Data zvernennia 11 Traven 2019], [in Ukrainian].

Kovalchuk, H.O., 1999. Aktyvizatsiia navchannia v ekonomichnii osviti: navchalnyi posibnyk [Start training in economic education: tutorial]. Kyivskyi natsionalnyi ekonomichnyi universytet [Kyiv National University of Economics]. K.: KNEU, [in Ukrainian].

Lemeshko L., 2018. Formuvannia khudozhno-tvorchoi kompetentnosti tekhnikiv-konstruktoriv odiahu yak problema profesiinoi pedahohiky [Forming clothes technicians-constructors' arts-creative competence as a professional pedagogy problem]. Naukovyi visnyk Instytutu profesiino-tekhnichnoi osvity NAPN Ukrainy. Profesiina pedahohika [Scientific herald of the Institute of vocational education and training of NAES of Ukraine. Professional Pedagogy], 16, s. 100-104. https:// doi.org/10.32835/2223-5752.2018.16.100-104, [in Ukrainian].

Maikovska, V.I., 2017. Sutnist i struktura pidpryiemnytskoi kompetentnosti maibutnikh fakhivtsiv v Ukraini [The meaning and structure of entrepreneurial competence of future specialists in Ukraine]. Visnyk Zhytomyrskoho derzhavnoho universytetu imeni Ivana Franka [Journal of Zhytomyr Ivan Franko University]. 1, s. 112-117, [in Ukrainian].

Odnoroh, H., 2018. Teoretychni zasady formuvannia kliuchovykh kompetentnostei uchniv u zakladakh profesiinoi osvity zasobamy interaktyvnykh tekhnolohii [The essence and structure of key competencies of future skilled sewing workers]. Naukovyi visnyk Instytutu profesiino-tekhnichnoi osvity NAPN Ukrainy. Profesiina pedahohika [Scientific herald of the Institute of vocational education and training of NAES of Ukraine. Professional Pedagogy], 16, s. 104-108. https://doi. org/10.32835/2223-5752.2018.16.104-108, [in Ukrainian].

Poiasok, T.B, 2003. Pryntsypy vidboru zmistu psykholoho-pedahohichnoi pidhotovky maibutnikh ekonomistiv [Some principles of selecting the content of psycho-pedagogical training for future economists]. Neperervna profesiina osvita: teoriia i praktyka [Unstoppable professional development: theory and practice], 1, s. 200-204, [in Ukrainian].

Radkevych, V., 2016. Teoretychni ta metodychni zasady rozvytku profesiinoi osvity i navchannia: rezultaty, problemy, perspektyvy [Theoretical and methodological basis of VETdevelopment: results, problems, prospective]. Naukovyi visnyk Instytutu profesiino-tekhnichnoi osvity NAPN Ukrainy. Profesiina pedahohika [Scientific herald of the Institute of vocational education and training of NAES of Ukraine. Professional Pedagogy], 11, s. 5-22.

Radkevych, O.P., 2012. Osoblyvosti pravovoho rehuliuvannia merezhi Internet [Features of legal regulation of the Internet]. Pravo ta upravlinnia [Law and Management], 1, s. 436-443, [in Ukrainian].

Tkalenko, N.V., 2011. Problemy pidhotovky suchasnykh ekonomistiv u systemi vyshchoi osvity [Some issues in the training of modern economists in higher education]. Naukovyi visnyk ChDIEU [Scientific Journal Chernihiv Economic University], 3 (11), s. 31-35, [in Ukrainian]. 
Hizrich, R. i Piters, M., 1992. Predprinimatelstvo, ili kak zavesti sobstvennoe delo i dobitsya uspeha. Vyp. 1. Predprinimatel i predprinimatelstvo [Entrepreneur and business, or how to seduce their own work and profit. You \& business; Vyp. 1]. Perevod s angliyskogo I. I. Andreeva, E. N. Nikolaenko. M.: Progress-Univers, [in Ukrainian].

Yablunovska, K., 2018. Teoretychni osnovy formuvannia ekolohichnoi kompetentnosti maibutnikh vykladachiv ahrarnykh zakladiv vyshchoi osvity [Theoretical bases of forming the ecological competence of the agrarian higher education institutions' future academic staff]. Naukovyi visnyk Instytutu profesiino-tekhnichnoi osvity NAPN Ukrainy. Profesiina pedahohika [Scientific herald of the Institute of vocational education and training of NAES of Ukraine. Professional Pedagogy], 15, s. 47-53. https://doi.org/10.32835/2223-5752.2018.15.47-53, [in Ukrainian].

Yershov, M.-O., 2019. Digitalisation of professional (vocational) and pre-high tertiary education of Ukraine: problems and prospects. Scientific herald of the Institute of vocational education and training of NAES of Ukraine. Professional Pedagogy, 1(18), pp. 67-74. https://doi.org/10.32835/2223-5752.2019.18.67-74, [in English].

УДК 378:658]:005.336.2:316.334.23

\section{Проблеми і перспективи формування підприємницької компетентності майбутніх бакалаврів з економіки підприсмства у процесі фахової підготовки}

\section{Інна Середіна,}

аспірантка Інституту професійно-технічної освіти НАПН України, завідувач навчальної лабораторії кафедри філософії та педагогіки Національного транспортного університету, м. Київ

Реферат. Актуальність дослідження зумовлена інтенсивним розвитком вищої економічної освіти в Україні та гострим запитом суспільства й вітчизняної економіки на підготовку фахівців, готових до реалізації професійної кар'єри в умовах розвитку малого бізнесу.

Мета: виявити й охарактеризувати сучасні проблеми і перспективи формування підприємницької компетентності майбутніх бакалаврів з економіки підприємства у процесі фахової підготовки.

Методи: класичний аналіз офіційних документів і наукових праць з формування і розвитку підприємницької компетентності: зовнішній аналіз (сприяв урахуванню історичних обставин створення відібраних документів як елементів певної системи суспільно-економічних відносин, визначенню його важливості та ефективності 3 огляду на визначену проблематику дослідження); внутрішній аналіз (зосереджувався на змісті джерела, сприяв виявленню проблем і перспектив формування підприємницької компетентності майбутніх фахівців у процесі фахової підготовки в закладах).

Результати. Показано, що сучасні науковці мають різні погляди на поняття “підприємництво”, але сходяться на думці про те, що успішність підприємницької діяльності залежить від рівня сформованості у випускників підприємницької компетентності. 3'ясовано, що в нинішніх умовах економіст-бакалавр повинен мати сформований науковий світогляд та широку ерудицію, демонструвати високу загальну культуру й належні моральні якості, володіти розвиненою підприємницькою компетентністю, постійно підвищувати рівень свого професіоналізму 3 урахуванням потреб економічного розвитку України. Виявлено, що здебільшого підприємницьку компетентність розуміють як сукупність особистісних і ділових якостей, навичок, знань, модель поведінки, володіння якими допомагає успішно вирішувати певні економічні завдання й досягати високих результатів діяльності.

Висновки: визначено основні проблеми формування підприємницької компетентності майбутніх бакалаврів з економіки підприємства (невмотивованість студентів до вияву підприємницької ініціативи; недостатній рівень формування готовності до підприємницької діяльності; незадовільний рівень сформованості підприємницької компетентності; недосконалість освітньої програми; наявність дисбалансу між професійними та ключовими компетентностями); окреслено перспективи формування підприємницької компетентності майбутніх бакалаврів з економіки підприємства (реформування системи національної освіти; розроблення і впровадження авторських програм з економічних дисциплін; введення у освітню програму спецдисциплін і спецкурсів, що сприятимуть формуванню підприємницької компетентності; діджиталізація вищої освіти; впровадження прогресивного зарубіжного досвіду формування готовності до підприємницької діяльності у практику вітчизняних 3ВО).

Ключові слова: підприємництво, економіка підприємства, компетентність, підприємницька компетентність, бакалавр.

Received: 19 September 2019

Accept: 04 November 2019 